audited accounts that are publicly available, and has received few complaints, Hernández says.

The survey includes only companies that itemize $\mathrm{R} \& \mathrm{D}$ expenditure in their financial reports. It also assigns firms to the country of their registered headquarters - even if their R\&D operations are located elsewhere. And fluctuations in foreign exchange rates greatly affect companies' relative positions in the rankings. In the case of the depreciation of the US dollar against the euro, for example, the scoreboard underestimates the R\&D growth rate of EU companies that have operations in the United States, and overestimates the growth rate of US companies that also operate in the European Union. And as the scoreboard's authors acknowledge, reporting practices and definitions of R\&D vary widely between companies and countries.

\section{Missing links}

Specialists also question whether absolute rises in R\&D investment actually correlate with competitiveness or innovation. Some argue that the relation between research budgets and financial outcomes is too complicated to be captured accurately in a ranking system such as the scoreboard.

"It's not the quantity, but the quality of R\&D that is most important," says Nick Von Tunzelmann of the science policy research unit at the University of Sussex, UK. He admits that such things are hard to measure, but says: "More could be done on the quality side of the scoreboard. The authors could look at how much bang the companies get for their buck."

Von Tunzelmann highlights several factors that make it difficult to draw broad conclusions from the scoreboard. Eastern Asia and the United States tend to dominate the most research-intensive industries, such as information technology, whereas European countries have traditionally been stronger in 'mediumtech' sectors such as automotive production and bulk chemicals.

And although the missing of the 3\% target may come as no surprise, the stubborn fact that only $55 \%$ of EU R\&D was last year undertaken by the private sector - well short of the the two-thirds that the European Union had targeted for 2010 - is an even bigger problem, Von Tunzelmann says.

Meanwhile, Von Tunzelmann contends that the role of R\&D is changing from an end in itself to a way to develop the capacity to undertake change. Ultimately, he says, companies need to be able to put $R \& D$ in its proper context.

"R\&D is only a part of the whole innovation effort," von Tunzelmann adds. "On the other hand, it is a fairly strategic part of the whole picture".

\section{IN BRIEF}

PATENTS UPHELD A US jury has ruled decisively for the pharmaceutical firm Amgen in a crucial patent lawsuit, finding that a competing anaemia drug made by Swiss drugmaker Roche infringed several patents belonging to the California-based biotechnology company. After the 23 October ruling, Amgen said that it would seek an injunction to prevent Roche from marketing its drug, Mircera, in the United States. Amgen has held a near-monopoly on the US anaemia market with its drugs Epogen and Aranesp, which together brought in sales of US $\$ 6.6$ billion last year. Roche said that it would consider an appeal if, as expected, the court confirms the jury's finding.

STEEL COUNT Steel makers have for the first time agreed to set up a system that will collect and report data for greenhouse-gas emissions by the industry on a consistent basis around the world. The International Iron and Steel Institute, based in Brussels, says that it will administer the scheme across the industry, which, it says, accounts for $3-4 \%$ of global man-made emissions. However, steel makers have not yet agreed on the extent to which the data for each plant should be made public - some companies have complained that this would require them to divulge confidential information about production levels.

AUTONOMY LOST A flagship of British biotechnology disappeared from view on 29 October when Cambridge Antibody Technology (CAT) was merged into Medlmmune in Gaithersburg, Maryland. Medlmmune is being developed into the biologicals arm of AstraZeneca, the pharmaceutical giant that bought it in April for $\$ 15.6$ billion. CAT, which was founded in 1990 and made its name developing antibody therapies, was acquired by AstraZeneca in 2006. CAT's operations will continue, as part of Medlmmune.

\section{MARKET WATCH}

\section{BIOTECHNOLOGY STOCKS}

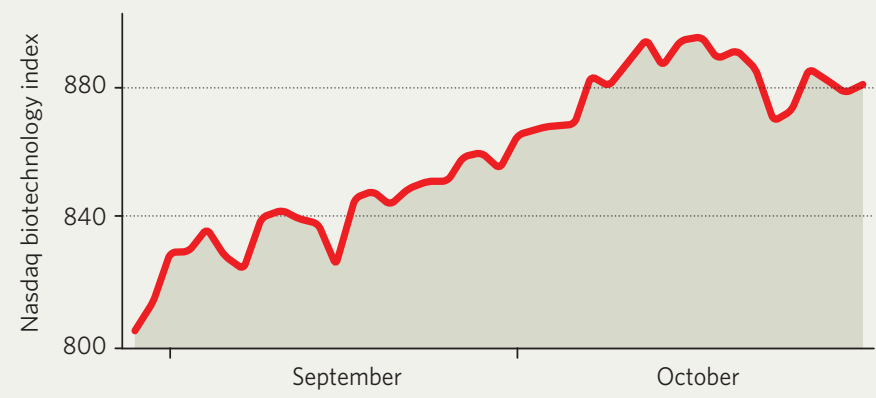

This week, Wood Mackenzie, an Edinburghbased research and consulting firm, reviews recent trends in biotechnology stocks.

The Nasdaq Biotechnology Index has been rising steadily, and is now up $10 \%$ from the end of August. This contrasts with a lack-lustre period from May onwards, and has a wide spread, with share prices up at 20 of the 25 most heavily weighted companies in the index.

The share gains reflect speculation that cash-rich pharmaceutical giants are set to buy up biotechnology firms to bolster weak drug-development pipelines and product portfolios threatened by competition from generic drugs.

This perspective was borne out on 12 October when Biogen Idec, the world's fifth biggest biotechnology company, said it was putting itself up for sale. Based in Cambridge, Massachusetts, the firm says that its sale is likely to offer shareholders better value than would be realized by the company's own strategic growth plans. Biogen Idec's shares jumped by almost $19 \%$ overnight on the announcement, with Pfizer touted as the most likely suitor. Sanofi-Aventis, Novartis, Johnson $\&$ Johnson and GlaxoSmithKline are also rumoured to be interested, but Pfizer is the most obvious buyer because drugs that account for about half of its revenue are expected to be facing generic competition by 2011. Of Biogen Idec's five approved drugs, two - Avonex and Tysabri - are treatments for multiple sclerosis, an area of strong strategic interest to Pfizer.

With Biogen Idec currently worth be the largest in the drug sector this year, pipping the $\$ 15$-billion acquisition of Medlmmune by AstraZeneca in April. And investors are betting that it would be just the first in a wave of biotechnology acquisitions by major pharmaceutical companies. some $\$ 23$ billion, any acquisition would 